筫 料

\title{
乾式再処理の現状と問題点
}

\author{
乾式再処理研究専門委員会の報告
}

\author{
乾式再処理研究専門委員会* \\ （1967年６月16日 受理）
}

\section{Present Status and Problems on Non-Aqueous Reprocessing}

By Special Committee on Non-aqueous Reprocessing

\begin{abstract}
A summary is given of the activities performed by the "Special Committee on Non-aqueous Reprocessing" in the two years from its establishment in April 1965 to its termination in March 1967. The review covers the present status of the studies undertaken, and the technical problems invoived in the non-aqueous processing of irradiated nuclear fuels. The subjects reviewed include such processes as pyrometallurgical, pyrochemical, chloride/fluoride volatility, and aquafluor.

The Committee also contributed to exchange of information through active discussions among the Committee members.
\end{abstract}

\section{まえがき}

動力用原子师の開発が盛んになるにつれて，核然料 サイクルの重要性はますをす注目されるようになっ た。その中でも再処理は濃縮ウラン燃料の有效利用の

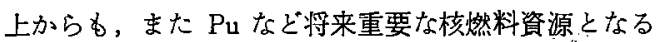
べき物質の回収の上からも重要である。従来諸外国で この再処理のために早くから工業化されたのは Purex 法などのいわゆる湿式法であって，原子归で照射済及 の燃料を，200日ほど冷却池で冷却したのち，脱被覆 後硝酸に溶解し，有機溶媒に上る溶媒抽出を行い，さ らに溶媒抽出またはイオン交換樹脂精製を行って， F.P. を十分に分離した U と Pu を回収する方法がと られている。わが国です1971年稼動を目標に $0.7 \mathrm{t} /$ 日 処理の湿式法による再処理工場の設計が原子燃料公社 によって進められている。

再処理のすう 1 つ方法である乾式法は湿式法に比 ベて,つぎのよ 5な利点を持っている。

（1）湿式法に比べてプロセスの数が少なく，かつ多 量の薄い酸溶液を取り扱わないので, 工場所要面 皘が少なくてすみ，建設費が安価である。したが
って，原子炉敷地に原子炉と結合して設置するこ とも可能でありこの場合には高価な使用済み燃 料の輸送費を節減しうる。

（2）有機溶媒，イオン交換樹脂等の有機物を用いな いので放射線損傷を受けにくく，したがって，冷 却期間を10日程度に短くすることができ，燃料の 炬外インベントリーコストを低減することができ る。

（3）放射性廃棄物は固体として得られるために体積 る小さく，取扱いゃ眝蔵が便利である。

\footnotetext{
* 委貣構成 (21名)(敬称略：@主査，○幹事)

石原 健彦(原 研)

过村 重男( …)

品川! 睦明(阪 大)

平野 見明( " ")

三好 正彦(原燃)

瀬川猛( ")

营野 卓治(東北犬)

荻原 善次( “ ”)

○須藤 欽吾(")

高島 洋一(東工大)

黒田正 ( ")

桐原 朝夫(名 大)

(O) 本寬(東大)

○督野昌義( “)

外山茂樹(東工試)

富 沢敏(")

富島広(東芝)

高島 耿生(三暴金属)

村田 寿典(日 立)

木下 秀男(古河雷工)

中沢 元一(住友金螨)

(設置期間1965年 4 月～1967年 3 月）
} 
（4）中性子の減速材である水を用いないので,プラ ントの設計に批いて臨界安全性の問題が湿式法の 場合よりる楽になる。

ししい，久点としては高温の操作を要し，各種反応 容器の腐食の問題もあり，とくに湿式法の F.P. の除 染係数が $10^{7} \sim 10^{9}$ 程度で非常に高いのに対して，乾式 法の中です高温冶金法などは 10〜 $10^{9}$ 程度と低いの で，取り扱 5 燃料は常に強放射性で，燃料の処理はも ちろんその後の成形加工, 検查まで遠隔操作を必要と する。しかし，最近とくに研究されているフッ化物揮 発法などは除染係数も $10^{8} \sim 10^{9}$ 程度に高いことが報じ られていて，必ずしす不利ではない。

現在湿式法に扣いて $10^{7} \sim 10^{8}$ とい5高い除染係数が 要求されるのは，燃料の再成形プロセスが直接加工で あるためであって，将来再循環 Pu が使用されること に伴って，遠隔加工が行われるよ5になれば，除染係 数として必ずしもこのような高い価を必要としない。 実際核的 poison の除去, すなわら反応度の維持とい 5観点からすれば，命却日数が 10 日以上あればD.F.

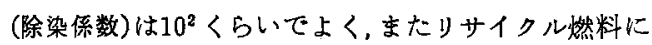
ついては，核分裂性物質の同位元素がかなりの放射能 をもつことが予想されるので，D.F.を大きく取ること はあまり決定的意㧴をるつことにならない。したがっ て将来の再処理法の 1 つして乾式法についてる十分 の考慮を払わなければならないと思われるので，われ われは，1965年 4 月，に本学会の研究専門委員会の 1 つ として乾式再処理研究専門委員会の設置を認められ， 本年 3 月に至るまで 2 力年にわたって各委員の熱心な 協力により国内および国外の研究開発の状況を調查す ると共に, 今後の発展のための問題点をある程度明ら かにしてきた。ここではその概要を簡単に報告する。 各プロセスの詳細については文献(1) を参考されたい。

乾式再処理法には，大別して「低除染法」と「高除染 法」とあり，低除染法には高温治金法, 高温化学法等が あり，高除染法にはフッ化物揮発法がある。その他に 湿式法と組み合わせた半乾式法等すある。

\section{I . 高温治金法}

高温冶金法は，使用斉み燃料を高温において融解し 蒸発，選択酸化還元等によって F.P. の除染，U,Pu の分離等を行 5方法で、つぎの上うないくつかの方法 がある。

\section{1. 融解精製法}

融解精製法はもっとも古くから研究され，アメリカ のANLのEBR-II 高速実験炻の燃料姏理にパィロット
プラント規模 (10 kgバッチ)で 1964年から処理が行わ れている。この原理はU-fs. 燃料ピソを $1,300^{\circ} \mathrm{C}$ 以上 で融解すると，Xe, KrなどのF.P.ガスゃ蒸気圧の高い F.P., Cs, Sr, Y, Ba あるいは I, Br などが蒸発除去さ れるはか，U上りも酸化物になりやすい F.P., Ce, La などは蒸発で除去されなかった Cs, Sr などと共に融解 のルッボのマグネシア、ジルコニアなどの酸化物と反 忍して，酸化物となり，表面に浮くスラッグとなり， あるいはルッボの壁面に固着したスカールとなって， 本体のUと分離される。しかし，D.F. は不十分なの で, EBR-II場合のよ5に遠隔操作で燃料ピンに Injection casting により成形できる場合の汪かは有利 ではない。

\section{2. 融解金属抽出法}

融解状態で照射済み燃料と相互に溶け合わない融解 金属を融解燃料金属と接触させて，この 2 相間の平衡 により，F.P.をその金属中に抽出除去したり，ある いは照射铜み燃料を溶媒となる他金属にとかし，F.P. と燃料金属との溶解度の差を利用して分別沈殿分離を 行 5方法で，接触金属として $\mathrm{Mg}, \mathrm{Ag}, \mathrm{Ca}$ 等を用いる 方法がある。分別沈殿の溶媒金属としてはZn, Cd等が 用いられ，EBR-II の燃料の融解精製法でF.P. の多く を含むスラッグあるいはルッボスカールの処理に一時 用いられた Pyrozinc 法が有名である。しかしここの 方法も D.F. が低いのでのちには金属塩法にとって 代わられた。

\section{3. 融解塩抽出法}

前述の融解金属の代わりに抽出剤として融解塩を用 いる方法で, 初期の頃 LMFR の燃料の処理に NaCl$\mathrm{KCl}-\mathrm{MgCl}_{2}$ の塩を用いて研究されたが, LMFR の研 究中止と共に中止された。燃料から塩中への抽出は溶 解度の差によるすのではなく，金属と塩との熱力学的 な安定度の差により，塩によって例えば塩化されやす いF.P.は塩になって塩中に入ることを利用する。は じめに述べた融解精製法では金属の表面に浮ぶスラッ グ中に F.P. を抽出するが，このスラッグは酸化物で 融点が高いのに，その代わりに塩を用いると融点的低 く低温操業で済み，また F.P. の抽出率すよいので， ANL では EBR-II の燃料㚮理に $\mathrm{BaCl}_{2}-\mathrm{CaCl}_{2}-\mathrm{MgCl}_{2}$ の塩を用いる方法も研究され，またここの方法を高速 炉のU-Pu 合金燃料の処理に用いる法も研究された。 しかし D.F. もまだ十分でない。溶解塩を用いて電解 を行ら方法もあり，D.F.は相当によく，Sr，Yなどで は 5,000 以上に達するが生成物の陰極からの回収に問 題があり，とくに工業化には取扱い上難点が多い。 


\section{4. 融解金属一塩法}

融解塭法が照射済み燃料そのものと塩を接触させる 方法であるのに対し，1度照射済み燃料を溶媒，例え ば $\mathrm{Zn}, \mathrm{Cd}$ などに溶かし，この金属相と融解塩とを接 解させる方法で，EBR-IIでは融解精製法のルッボス カールの処理に Pyrozinc 法の代わりに用いている。 これに上ると融解塩抽出法と融解金属抽出法を組み合 わせて行えるので，それぞれ単独で行らよりも遥かに D.F.が高い。ANL では EBR-II の加に，高速师の 燃料処理用として溶媒金属に $\mathrm{Cd}-\mathrm{Zn}-\mathrm{Mg}$ ，塩に $\mathrm{LiCl}$ $\mathrm{NaCl}-\mathrm{MgCl}_{2}-\mathrm{ZnCl}_{2}$ を用いた方法を研究している。

しかし、これらはU,Pu とF.P.との分離ができるだ けであって，Uと $\mathrm{Pu}$ の分離のためには，ブランケッ 卜の処理のために, Puは $\mathrm{Mg} の$ 多い $\mathrm{Mg}-\mathrm{Zn}$ 合金には よく溶けるが，Uはわずかしか溶けないことを利用し た一種の融解金属抽出法を考え，ついて，溶媒金属を $\mathrm{Cu}-\mathrm{Mg}$ '合金に代え，さらにこれを $\mathrm{NaCl}-\mathrm{KCl}-\mathrm{MgCl}_{2}$ と接触さぜて U,Pu と F.P. との分離扰上びUと $\mathrm{Pu}$ との分離の両方を行 5方法を開発している。しか し、いずれにしてもまだ実験的段階であって工業化す るためには，取扱いその他問題が多い。

\section{5. その他の方法}

その他にる高温冶金法としては，Ge や $\mathrm{Si}$ の精製に 用いられるような Zone-melting の方法や，初期の頃 Zr の精製に用いられにョウ化物分解法などがあるが， 取り扱える量が少量であっこ，工業的には問題になら ない。

以上の方法は大体金属燃料の処理に限られているの に対し，最近はセラミック燃料の処理方法の研究も進 捗をみている。

\section{II. 高温化学法}

\section{1. 酸化物燃料処理法}

この中の 1 つは A.I. (Atomics International社) で研 究された酸化還元サイクル法であって, “Airox 法”と る呼ばれ，被覆管を切断して孔を一定間隔であけたも のを酸化すると内部の $\mathrm{UO}_{2}$ ペレットは $\mathrm{U}_{3} \mathrm{O}_{8}$ になり， このとき体積が多くなるため粉末化して脱落してく る。これを水素で還元して UO $\mathrm{UO}_{2}$ にする。これを繰り 返すと粉末は次第に微細となり，焼結に適したUO なり，金属として蒸発しやすい Sr,Cs などは還元段 階で, 酸化物として蒸発しゃすい Mo, Ru などは酸化 段階で除去される。A.I. ではこの低除染法で数サイク ルの燃料利用が可能であるとしてコストの試算まで行
なっているが，燃料の遠隔加工に問題があり，研究は 中止されている。

これに対しアメリカのHanford研究所(North Western Pacific Battelle Lab.)では塩サイクル法といって, $\mathrm{UO}_{2}-\mathrm{PuO}_{2}$ 燃料処理のための電解法を研究している。 この方法によれば，まず照射済み燃料の被㨽を除去し たのち，酸化して粉末とし， NaCl-KCl の融解塩中に 塩素または塩化水素ガスを吹き込みながら燃料を溶か して $\mathrm{UO}_{2} \mathrm{Cl}_{2}, \mathrm{PuCl}_{3}$ とし，塩素を吹き込みながら電解 して $\mathrm{Pu}$ を含まない $\mathrm{UO}_{2}$ たけを電着させ，その後 $\mathrm{Pu}$ の濃縮された $\mathrm{UO}_{2}-\mathrm{PuO}_{2}$ 混合酸化物を電着採取する か，または塩素一酸素の適当な割合のガスを吹き込ん で $\mathrm{PuO}_{2}$ を化学的に沈殿させて分離する。この方法の 経済的評価むなされているが，各種の条件のわずかな 違いによって D.F. や Puの浱縮度が異なり，一定組 成の成品を得るにはまだ問題が多い上うである。

\section{2. 炭化物鷀料処理法}

将来高温ガス冷却炉，有機材減速炉，ナトリウム冷却 炉などの燃料として有望視されている炭化物系燃料の 再処理法としても高温化学法が考えられ，その主なる のは炭化物一酸化物一炭化物サイクル法, 炭化物一于 ッ化物一炭化物サイクル法, 融解塩電解法などであ る。炭化物一酸化物一炭化物サイクル法は Carbox 法 とも呼ばれ, 主にA.I. で研究されている方法でUC+ $2 \mathrm{O}_{2} \longrightarrow \mathrm{UO}_{2}+\mathrm{CO}_{2}$ (約 $400^{\circ} \mathrm{C}$ ), $\mathrm{UO}_{2}+3 \mathrm{C} \longrightarrow \mathrm{UC}+2 \mathrm{CO}$ $\left(1,300^{\circ} \mathrm{C}\right.$ 以上)の 2 つの反応に上り，第 1 の反応で UC を 1 度酸素,空気などで酸化して粉末化し，このとき ガス状のF.P.や高揮発性のF.P.を除き，第 2 の反応で さらに高温て揮発性の F.P. を除去できる。第 2 の反

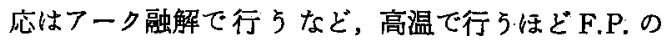
除染は上いが，Puの大部分も同時に揮発して失われ るので，高速炉のブランケットの処理には適さない。

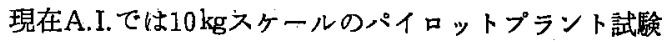
が行われているが，工業化には種々問題がある。

炭化物一チッ化物一炭化物サイクル法も A.I. で研

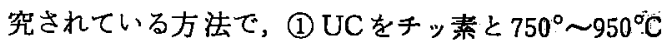
で反忘させて粉化し， $\mathrm{U}_{2} \mathrm{~N}_{3}$ とC との泿合物とし，(2) これを $1,300^{\circ} \sim 2,100^{\circ} \mathrm{C}$ に加熱して再び UC にもど し，(3このUC をアーク融解して残留チッ素を除く と同時にF.P.の一部を除いて燃料体を作る工程からな る。Carbox 法々同様, 第 1 の段階では岕まりF.P.の 除去は見られず，第 2 の段階で Cs, Sr の95\%,R.E.の 約50\%, Ce の20〜60\%が除かれるが; Pu は損失とな るし，除染率の低いことや工業化の面で問題が女る。 融解塩電解法は，UC索極として $\mathrm{LiCl}-\mathrm{KC}$. 等の 
融解塩中て電解し除染を行うと同時に，陰極のMo上 に金属Uを析出させ，これと炭化水素ガスとの反応で 再びUCにもどす方法で，除染率は高温化学法の中で は最もよく $\mathrm{Sr}, \mathrm{Ba}$, R.E., Ce, Ru等に対しては $10^{3} \sim 10^{4}$ のD.F、が得られているが，操業のコントロールが難 しくまた一定組成のUC を得にくい久点がある。

以上述べたよ 5 に高温冶金法, 高温化学法は除染率 が低いので，その一部には研究を続行方る価值のある ものするるか，遠隔操作燃料加工が一般化しない限り 工業化を考える段階にはないと見てもよいである5。

\section{I. 塩化物揮発法}

㫫化物揮発法は照射済み核燃料を $\mathrm{Cl}_{2}, \mathrm{HCl}, \mathrm{CCl}_{4}$ 等 て塩化し，塩化物の揮発性の差や，固体塩化物への選 択吸着, 眖着等を用いて F.P. やU, Pu の分離を行 方法であって，ORNL のZircex 法の上うに湿式法の 前処理として。，市るいはアメリカの ANL，ペギーの Mol, フランスの Fontenay-aux-Roses の上うにつぎ に述べるフッ化物揮発法の前処理として研究されてい るほか，塩化物揮発性のみで全処理を行う研究が， た ルギーの Mol, 東ドイッの Rossendorf, アメリカの O RNL, 日本の原研等で行われた。

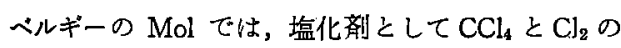
混合ガスを用い, Rossendorf では $\mathrm{CCl}_{4} と \mathrm{CO}_{2}$ の混 合ガス， ORNL では $\mathrm{Cl}_{2}$ と $\mathrm{CCl}_{4}$ の混合ガス，原研で は $\mathrm{CCl}_{4}$ ガスを用いているが，F.P.の D.F. がいずれ す蒸留だけでは50以下と低く，原研で $\mathrm{NaCl}, \mathrm{BaCl}_{2}$ な どの固体吸着材を用いた場合ですD.F.は最高 $10^{3}$ 程 度であって，高温冶金法や高温化学法と同様に然料の 成形加工に遠隔操作を必要とし，また Pu の塩化物に ついての知識が不足である久点もあるので, 各研究所 では,つぎ述べるフッ化物揮発法の研究に重点を置 くようになってきた。

\section{IV. フッ化物揮発法}

フッ化物揮発法は高温冶金法等と同時代から研究さ れ，乾式法の利点をすへて具備する上に除染係数が $10^{8}$ $\sim 10^{10}$ と湿式法と同等あるいはそれ以上であり，分析 法, 保守, 遠隔操作等の点で問題が残されているが，乾 式法の中ではるとも早く工業化が期待されている。 フッ化物法の研究はアメリカの ANL, BNL, QRNL, フランスの Fontenay-aux-Roses, ベルギーの Mol 研 究所等で行われ，イギリスでは全く研究が行われてい ない。れら諸外国に括ける開発目標は MTR, ETR， 艦船炉等の高髷縮ウラン合金燃料の処理と，動力炉用
低濃縮セラミック燃料の処理に分かれ，最近では高速 炉燃料への適用も検討されている。

\section{1. 高瀑縮ウラン合金燃料処理}

高濃縮ウラン合金燃料についてはすすでに10年前上 クパイロットテストが行われ，ORNL の融解塩法(50 $\mathrm{kg} / \therefore ッ$ )によって, U-Al, U-Zr 合金然料について 高除染が実証された。融解塩法では，U-Zr，U-Al 合

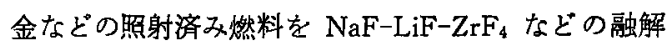
塩中に HF ガスを吹き込みながら溶かし，この塩中 で UF $\mathrm{UF}_{4}$ になったUを,さらに $\mathrm{F}_{2}$ ガスを塩中に吹き 込むことによって UF 6 として揮発させ，冷却トラッ プに回収する。この際, 不揮発性 F.P. フッ化物は塩 中に残って分離される。一部 $\mathrm{UF}_{6}$ とともに揮発して

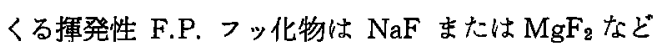
の固体ベッドに上る吸着脱着で分離され，全体として D.F. は107〜1010 に達したとい5。この方法はプロセ スも確立し，実用化の見通しも持たれたことがある が, 融解塩を入れる溶解槽の材料の研究を相当に行な ったが，依然としてその腐食が激しく，また低濃縮ウ ラン然料に適用した場合には融解塩からの Puの分離 か困䨀で，つぎに述べる ANL その他の研究所で開発 され，近年著しい発展を遂げた流動層を用いるガスに よるフッ化法が，これに代わって実用化されると思わ れる。

高濃縮ウラン燃料処理の流動層法はアメリカの AN L のほか, フランスの Fontenay-aux-Roses, ベルギ 一の Mol などの研究所で研究開発されている方法で, 照射済み燃料を処理する前に，被覆材や合金材料の $\mathrm{Zr}$ や $\mathrm{Al}$ を分離するため，まず流動層中で $\mathrm{HCl}$ ガスに上 る塩化を行い，Zr は $\mathrm{ZrCl}_{4}, \mathrm{~A} 1$ は $\mathrm{AlCl}_{3}$ として揮発 除去させる。U と分離された $\mathrm{ZrCl}_{4} ゃ \mathrm{AlCl}_{3}$ は，別 の流動層中で水蒸気と反応させて酸化物として眝蔵す る。U は初めの流動層中に $\mathrm{UCl}_{3}$ の形で残留するか らここ机 $\mathrm{HF}$ または $\mathrm{F}_{2}$ ガスを送入することによっ て UF $\mathrm{UF}_{6}$ とし， $\mathrm{NaF}$ による吸着脱着などによってさら に除染を行う。この方法は除染率的高く, ANL では $30 \mathrm{~kg} /$ ハッチのパイロットプラントで研究がなされて いる。 $\mathrm{Mol}$ 研究所ではフッ化剂として $\mathrm{SF}_{4}, \mathrm{ClF}_{3}$ など を用いる研究が行われている。フランスでは ATTIL A-1計画と称して1969年よりMTR の燃料を処理する パイットプラントを操業する計画を立てており，さ らに第 2 段階として ATTILA-2 計画で高速增殖炑の 燃料を1971年頃より処理する計画を立てている。フラ ンス側の意見では，天然ウラン燃料の処理については 乾式法は湿式法には比較し得ないといらことである。 


\section{2. 低溒縮ウラン然料再処理}

低濃縮ウラン燃料は現在の動力用原子炉の燃料で最 も重要な対象であり，燃料は $\mathrm{UO}_{2}$ セラミックスでス テンレス鋼またはジルカロイ被覆をされている。さら にこの場合は，処理する燃料に 0.4〜1.5\%程度の $\mathrm{Pu}$ が含まれているために，Pu の分離回収が重要である。 この方法はフランス、ペルギーでも実験室規模では行 われているが，特にアメリカでは実験室規模からパイ ロットプラント試験まで併行して進められている。

この工程は脱被覆, フッ素化, 除染(分離回収)，燃料 再製の各段階からなるが，ジカロイ被覆は高濃縮ウ ラン燃料処理の場合と同様に $\mathrm{HCl}$ との反応で $\mathrm{ZrCl}_{4}$ と して揮発除去されるが，ステンレス鎆被覆の場合は $\mathrm{O}_{2}$ あるいは $\mathrm{O}_{2}+\mathrm{HF}$ による酸化によって除去され る。フッ素化は $\mathrm{BrF}_{5}, \mathrm{ClF}_{3}$ を用いる方法も最近研究さ れているが，主な方法は HF と $\mathrm{F}_{2}$ による 2 段反応 または直接 $\mathrm{F}_{2}$ による 1 段反応である。ベルギーで研 究されているのはつぎのような

$$
\mathrm{U}_{3} \mathrm{O}_{8}\left(\mathrm{UO}_{3}\right) \stackrel{\mathrm{H}_{2}}{\longrightarrow} \mathrm{UO}_{2} \stackrel{\mathrm{HF}}{\longrightarrow} \mathrm{UF}_{4} \stackrel{\mathrm{F}_{2}}{\longrightarrow} \mathrm{UF}_{6}
$$

の反応による 2 段階フッ化反応で，高価格の $\mathrm{F}_{2}$ 使用 量が 1 段階反応より少ない利点があるが，装置の腐食 は HF のほうが激しい。ANLでは 1 つ不活性フル ミナの流動層の下部で $\mathrm{O}_{2}$ による酸化て脱被德し，上 部で $F_{2}$ によるフッ化を行 52 層式流動層を研究して いた。しかし 2 層流動層は, 酸化層からの $\mathrm{U}_{3} \mathrm{O}_{8}$ 粉末 供給量変動に上る $\mathrm{UF}_{\mathrm{G}}$ 生成速度変化が大きいなどの 欠点があり，現在では別々の流動層で行われるよ5に なった。F.P. の除染については，従来高除染を得て いる $\mathrm{NaF}$ ベッドに上る吸着脱着法は少量のUを扱う 場合はよいか，低濃縮ウラン燃料処理の場合のよ5に 大量のUを処理しなければならない場合には，蒸留法 の適用考虑しなければならないが，蒸留法による分 雖の詳細はあまり研究されていない上5である。低濃 縮ウラン燃料処理の場合に重要な U, Pu の分離につい ては, (1) $\mathrm{PuF}_{6}$ が熱分解してPuF 4 の固体となって分離 される熱分解法，(2) NaF K上る $\mathrm{UF}_{6}$ の吸着加可逆 的であるのに対し， $\mathrm{PuF}_{\mathrm{B}}$ の吸着が不可逆的であるこ とを利用する固体吸着法，(3)例えばフレオンで $\mathrm{PuF}_{6}$ は $\mathrm{PuF}_{4}$ に還元されるか UF $\mathrm{UF}_{6}$ はそのままであること を利用する選択還元法， (4) UF $\mathrm{U}_{\mathrm{B}}<\mathrm{PuF}_{\mathrm{B}}$ との蒸気圧の 差を利用する蒸留法などが研究されているがここのU -Pu の分離はフッ化物揮発法の中最す困難な問題であ って, 最近の研究はこの方面に集中されている。 その1つは買択つッ化法で, (3)と似たような原理で
あるが， $\mathrm{ClF}_{8}$ や $\mathrm{BrF}_{5}$ などで $\mathrm{UO}_{2}-\mathrm{PuO}_{2}$ をフッ化す るとUのみ $\mathrm{UF}_{6}$ になり， $\mathrm{Pu}$ は $\mathrm{PuF}_{4}$ までしかフッ 化されないことを利用する方法が研究されている。

低濃縮ウラン燃料の処理について，アメリカでは ANL や BNL, ORNL の基碳研究をもとにORNLに 1969年までに 40〜100 kg/ハ \%の規模の流動層式パ イロットプラントを建設する計画を立てているようで ある。またアメリカでも,フッ化物揮発法に上る高速 増殖炉の燃料再処理を候補として考虑し、コストを試 算している。

3. 半乾式法(アクアフルオル法)

最近アメリカのG.E. 社および Allied Chemical 社 ではフッ化物揮発法で確信の持てないUと $\mathrm{Pu}$ との分 離および Puの精製を従来技術的に確立した湿式法で 行い,Uからの F.P. の除去とUの回収だけをフッ化 物揮発法で行 5 湿式法, 乾式法の混合法ともい5べき 半乾式法(アクフフルオル法) と称する処理法を開発中 で，G.E.ではこの方法にすとずいた再処理工場を1969 年までに建設する予定と伝えられる。このことから判 定すれば, G.E. ではフッ化物揮発法において，U，Pu の分離のみが残されれた問題で，その他の事項は全く解 決していると推定される。しかしこの方法は，乾式法 の長所と湿式法の短所を合わせ持っており，この程度 の乾式法の組合せでは乾式法の長所を十分に発揮でき るとは考えられない。とくにこの方法はもっとも高放 射性の物質を取り扱 5 初期工程に，放射線に弱い有機 溶媒やイオン交換樹脂を使 5 点で湿式法より優れてい るとはいえない。

\section{4. フッ化物揮発法の経済性}

フッ化物揮発法の経済性にはこの姏理に必要なフッ 素の価格が重要な意味をるっている。アメリカで Allied Chemical 社によって生産されているフッ素の価 格は3.5\$/lb といわれる。一応この価格を採用して 2,700 円 $/ \mathrm{kg}$ とし，フッ素の利用率を $f$ とすると $300 \mathrm{t} / \mathrm{y}$ の規模のプラントにおけるフッ素の費用は 3 億 9,000 万円 $/ f / y$ となる。

原燃の第 1 号湿式法プラント $(210 \mathrm{t} / \mathrm{y})$ の直接操業費 が 7 億円/年であることを考えると、フッ素の費用は相 当に大きいるのである。な扰，2段階反応を用いるこ とにすればフッ素の2/3は HFに置き代えられ，HF の 価格は日本において 500 円 $/ \mathrm{kg}$ 程度であるから、この場 合には相当に費用が下がることになる。

まだ多くの未知な要因があるので，湿式法，乾式法 の再処理コストの正確な比較は困難であるが，1例を あげると第 1 表のよ 5 な発表がある(2)。 
第1表 湿式法, 半乾式法, $7 ッ$ 化物揮発法の 経済比較

\begin{tabular}{|c|c|c|c|}
\hline & $\begin{array}{l}\text { AEC 試 } \\
\text { 工場建棓 } \\
10^{6}(\$) \\
\end{array}$ & $\begin{array}{l}1 \mathrm{t} / \mathrm{d} \\
\mathrm{s}\end{array}$ & $\begin{array}{l}\text { Allied Chemical } \\
\text { 試算工場建設費 } \\
\text { 相 対 值 }\end{array}$ \\
\hline \multirow{3}{*}{$\begin{array}{l}\text { 湿式，法 } \\
\text { 半乾式 法 } \\
\text { ᄀ } x \text { 化物揮発 } \\
\text { 法 }\end{array}$} & 30 & 108 & 100 \\
\hline & 27.5 & 99 & $65 \sim 70$ \\
\hline & 17.5 & 63 & 50以下 \\
\hline
\end{tabular}

参考のために原燃第 1 号プラント $(0.7 \mathrm{t} / \mathrm{d})$ の建設費 は 130 億円とされている。さらに高速炉を対象とした 湿式法, フッ化物揮発法, 高温化学法のコスト比烄 ${ }^{(3)}$ が $^{\circ}$ 発表されているので第 2 表に示す。これは $1,000 \mathrm{MW}$ (e)FBR 1 基あるいは 3 基を原子㸝敷地内方式で処理 する場合と，1,000 マイル以内の 10 基を集中方式で処
理する場合について計算してある。そしてこれは燃料 化合物への転換までのコスト計算であり，再加工費用 は含まれていない。

これらの経済性の比較にはまだ多くの仮定が含まれ ていると思われ，固体廃衰物，廃ガスの処理,バルブ， ポンプなどの開発，その遠隔操作，保守，その他計測，分 析方法の確立など, フッ化物揮発法の工業化までには まだ解決を要する問題が多々女りこれらについての 発表はあまり行われて扣らず，乙の詳細な経済的評価 を行うためには，さらに今後の研究開発にまつべき点 加多い。

な挌，本報で，とりあげた研究は，1967年 3 月以前 になされたるので，その後の研究については触れてい ないことをご了承願いたい。（文責 菅野昌義）

第 2 表 高速师の各種燃料の湿式法と乾式法に上る再処理コストの比較

\begin{tabular}{|c|c|c|c|c|c|c|c|c|c|}
\hline \multirow{2}{*}{ 燃料形体 } & \multicolumn{3}{|c|}{$\begin{array}{c}\text { 原子师敷地内方式 } \\
1,000 \mathrm{MW}(\mathrm{e}) \text { I 基 }\end{array}$} & \multicolumn{3}{|c|}{$\begin{array}{c}\text { 原子护敷地内方式 } \\
1,000 \mathrm{MW}(\mathrm{e}) 3 \text { 基 }\end{array}$} & \multicolumn{3}{|c|}{$\begin{array}{l}\text { 集 中 方 } \\
1,000 \mathrm{MW}(\mathrm{e}) 10 \text { 基 }\end{array}$} \\
\hline & 湿式法 & 揮 発 法 & 高温化学法 & 湿式 法 & 揮 発 法 & 高温化学法 & 湿式法 & 揮 発 法 & 高温化学法 \\
\hline 金 偊 & 0.93 & 0.62 & 0.49 & 0.59 & 0.40 & 0.30 & 0.46 & 0.40 & 0.34 \\
\hline 酸化物 & 0.87 & 0.58 & 0.67 & 0.54 & 0.37 & 0.41 & 0.44 & 0.39 & 0.42 \\
\hline 炭化物 & 0.96 & 0.66 & 0.69 & 0.58 & 0.42 & 0.42 & 0.47 & 0.42 & 0.43 \\
\hline
\end{tabular}

単位：mills $/ \mathrm{kWh}, 308$ かけると $\$ / \mathrm{kg}$ となる。

\section{一参考 文 献一}

（1）菅野昌義：被照射核燃料の乾式再処理，(I) （V)， 新金属工業, No.127 131，（1966）.

（2）鎌田 稳： アメリカに的ける使用済み燃料の再処 理，原子燃料公社再処理資料No.14，(1965).
(3) M.V. Levenson, G. Trice., Jt., W.J. Mecham: Comparative Cost Study of the Processing of Metals, Oxide and Carbide Fast Breeder Reactor Fuels by Aqueous, Volatility and Pyrochemical Methods, $A N L-71.73$, (1966).

\section{第 2 回原子力施設と沿岸海洋シンポジウムのご案内}

共催 原子力安全研究㙝会, 本 会, 他

とき 10月31日(火) 10:00 17:00

上ころ 気象庁 講堂(千代田区大手町 1 -7)

ブログラム

挨 拶

座長 檜山義夫(東大)

1. 欧州に扣ける放射性廃寨物の沿岸放出上 環境污染市川竜資(故医研)，谷井潔(東水研)

2. 沿岸放出の現状 丸山正偷 (原 燃)

3. 試算分科会の第工次試算報告畫について

畳田和久(原 研)
座長 速水頌一郎(東海大)

4. 放出方法分科会のマスタープラン

5. 海洋分科会のマスタープラン 座長 松平近義(東北大)

6. 生物分科会のマスタープラン 佐伯誠道(放医研)

7. 化学分科会のマスタープラン 池田長生(乎教大)

8. 䋓括討論 座長 三宅泰雄(教育大) 